\title{
Luminescent Probe for Crotoxyphos Pesticide Detection Based on Eu (III) Complex with 7-Hydroxy-Coumarin-4-Acetic Acid
}

\author{
Azab H. A. ${ }^{1}$;. A. Ibrahim ${ }^{1}$; N. Hassan ${ }^{2}$ and H. M. Darwish ${ }^{1^{*}}$ \\ ${ }^{1}$ Chemistry Department, Faculty of Science, Suez Canal University, Ismailia, 41522, Egypt. \\ ${ }^{2}$ Chemistry Department, Faculty of Science, Port Said University, Port Said, Egypt.
}

Received: .7/8/2016

\begin{abstract}
Luminescent Europium complex based on7-hydroxy-coumarin-4-aceticas ligand was investigated as a probe for the detection of organophosphorus pesticides. The complex exhibited an interesting action towards Crotoxyphos pesticide. The luminescence of the Eu(III)-7-hydroxy-coumarin-4-acetic was remarkably enhanced by gradual addition of Crotoxyphos. Limit of detection (LOD) $=1.86 \mu \mathrm{M}$ and limit of quantitation (LOQ) $=6.19 \mu \mathrm{M}$. Binding constant at different temperatures was calculated according to Benesi-Hildebrand equation. The thermodynamic parameters $\Delta \mathrm{H}, \Delta \mathrm{S}$ and $\Delta \mathrm{G}$ were calculated for characterization of the nature of force due to interaction of the complex with Crotoxyphos. Finally, the effect of interfering anion and cations that naturally occur in water and soil was studied, in addition; interference of some pesticides was studied.
\end{abstract}

Keywords: Luminescence probe, Europium, Coumarin derivative, Crotoxyphos.

\section{INTRODUCTION}

Organophosphorous pesticides are the most widely used group of insecticides, worth nearly $40 \%$ of the market sales (Singh and Walker 2006;Anonymous, 1996). Organophosphorous pesticides are acetylcholinesterase (AChE) inhibitors. These pollutant move in environment by volatilization, leaching and runoff (Sawhney et al., 1989). Monitoring pesticides in environment depended on expensive chromatographic methods for decades, new novel methods has been submitted to achieve the fast, reliable, cheap and selective qualitative and quantitative detection of pesticides e.g. AChE-based biosensors (Carlo et al., 2004; Vakurov et al., 2004; Bucura et al., 2006), Lateral field excited acoustic sensor with polymer coating (Yihe Huet al., 2005), Carbon paste electrochemical transducer (Liu and Lin, 2005), Fluorescence (Jenkinset al., 1999; Russell et al.,1999; Viveros et al., 2006), Potentiometric ion-selective electrode (Rainina et al., 1996; Ristori et al., 1996), pH-sensitive field-effect transistor (Simonian et al., 2001), Amperometric microbial detection (Doicket al., 2005, Mulchandaniet al.,2006), Quantum dots (Tang et al., 2016; Zhang et al., 2010), Surface enhanced Raman spectroscopy (Nguyen et al., 2014;Bin Liuet al., 2013) and Nanoparticle-Based Chemiluminescent Sensor (Yi He et al.,2015).

In this work, we study and improve a selective probe for Crotoxyphos pesticide based on $\mathrm{Eu}(\mathrm{III})-7$ hydroxy-coumarin-4-acetic, this probe based on lanthanide as approach in Analytical sensors (Bünzli and Eliseeva, 2011).7-hydroxy-coumarin-4-acetic (Figure 1) is a comarin base derivative, they are sensors for ions (El-Shekheby et al., 2014), pesticides (Obare et al., 2010). Although comarins are good lanthanide sensitizers (Husseinet al.,2016; Féau et al., 2009). This work shows the selectivity of luminesncet Eu(III)-7hydroxy coumarin-4-acetic acid toward Crotoxyphos pesticide.

\section{MATERIALS AND METHODS}

\section{Materials}

Europium chloride hexahydrate $\left(\mathrm{EuCl}_{3} \cdot 6 \mathrm{H}_{2} \mathrm{O}\right)$ was analytical grade and purchased from Sigma-Aldrich. The stock solution was prepared in Ethanol. Solvents were purchased from Sigma-Aldrich and Fisher chemicals HPLC grade.

Material used in organic synthesis and salts used in work were AR grade and used without further purification included: Heavy metals (Nitrate of $\mathrm{Ni}^{2+}$, $\mathrm{Cd}^{2+}$ and $\mathrm{Pb}^{2+}$ ), Alkali metals (Chlorides of $\mathrm{Ca}^{2+}, \mathrm{Na}^{+}$ and $\mathrm{K}^{+}$also $\mathrm{NH}_{4}^{+}$), Anions (Sodium salt of $\mathrm{CO}_{3}{ }^{2-}, \mathrm{NO}_{3}{ }^{2-}$ $, \mathrm{H}_{2} \mathrm{PO}_{4}^{-}, \mathrm{HPO}_{4}^{2-}, \mathrm{Br}^{-}$, and $\mathrm{I}^{-}$).Pesticides used in work included Dichlorvos (P1), Malathion (P2), Crotoxyphos (P3), Chlorpyrifos (P4), Paraoxon (P5), Profenofos (P6), Endosulfan (P7) and Heptachlor (P8). All pesticides are analytical standard brought from Sigma-Aldrich.<smiles>O=C(O)Cc1cc(=O)oc2cc(O)ccc12</smiles>

7-Hydroxy Coumarin-4-acetic acid

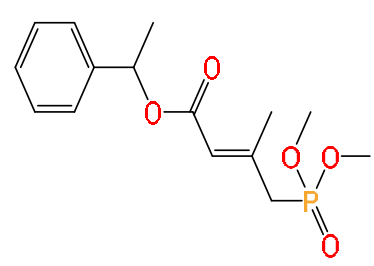

Crotoxyphos (P1)
Figure (1): Chemical structure of 7-Hydroxy coumarin4-acetic acid and Crotoxyphos

\section{Chemical and physical measurements}

${ }^{1} \mathrm{H}-\mathrm{NMR}$ performed on Bruker Ascend $850 \mathrm{MHz}$. Infrared spectra were obtained on 4100 JASCO Japan FT-IR. Fluorescence spectra were performed on Jasco FP-6300 spectrofluorometer $1.0 \mathrm{~cm}$ path using Hellmaquartz cell type 111-QS with a $150 \mathrm{~W}$ xenon lamp for excitation. Absorbance spectra (UV-VIS) were carried out using Shimadzu UV-1800, Double Beam photometric system, and $1.0 \mathrm{~cm}$ path length cell. 


\section{Methods}

Preparing complex and testing samples were achieved by using stocks solutions of materials and adding a precise volume of them to solvent, then stir using vortex action, the desired measurement was taken at room temperature $22-24^{\circ} \mathrm{C}$ or using a water bath to rise sample temperature. UV-Absorption measurements in $1 \mathrm{~cm}$ quartz cell. Fluorescence measurements in $1 \mathrm{~cm}$ quartz cell and excitation wavelengths based on excitation and absorption spectra.

\section{RESULTS AND DISCUSSION}

\section{UV Absorption Spectra}

Absorption spectra of 7-hydroxy coumarin-4acetic acid $\left(\mathrm{C}_{1}\right)$ areillustrated in figure (2) in ethanol where two absorption bands observed at 219 and 325 $\mathrm{nm}$, the first one may be attributed to $\pi \rightarrow \pi^{*}$ and the second one could be assigned to $n \rightarrow \pi^{*}$ transition. $\mathrm{Eu}(\mathrm{III})-\mathrm{C}_{1}$ complex exhibit two absorption bands at 220 and $326 \mathrm{~nm}$, where there is a very small shift in absorption peaks to red in comparison to the free $C_{1}$ ligand. Two broad weak peaks are observed at 244 and $245 \mathrm{~nm}$. This indicative of complex formation.

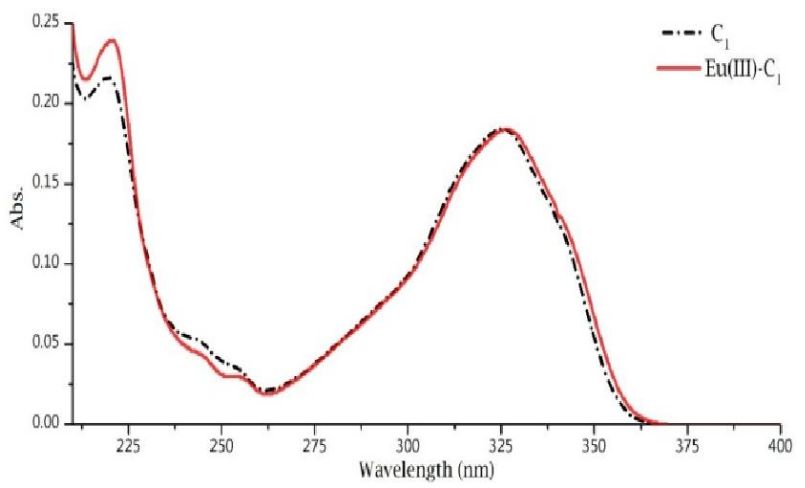

Figure (2): UV-absorption spectra of $[10 \mu \mathrm{mol} / \mathrm{L}] \mathrm{C}_{1}$ and with $[10 \mu \mathrm{mol} / \mathrm{L}] \mathrm{Eu}^{3+}$ in ethanol.

\section{Fluorescence of $\mathrm{Eu}(\mathrm{III})-\mathrm{C}_{1}$ and Interactions with Pesticides \\ Fluorescence of $\mathbf{E u}\left(\right.$ III)- $\mathrm{C}_{1}$.}

Like majority of Coumarins (Féau et al., 2009), $\mathrm{C}_{1}$ has strong fluorescence and upon complexation with Europium with $\mathrm{C}_{1}$ in molar ratio 1:1 make a noticeable change in fluorescence spectra of coumarin $\left(C_{1}\right)$ which interpreted due to complex formation and energy transfer to $\mathrm{Eu}(\mathrm{III})$ center. Two characteristic bands of $\mathrm{Eu}(\mathrm{III})$ were observed; one at $\lambda_{\mathrm{Eu} 1}=592 \mathrm{~nm}$ correspond to ${ }^{5} \mathrm{D}_{0} \rightarrow{ }^{7} \mathrm{~F}_{1}$ and $\lambda_{\mathrm{Eu} 2}=617 \mathrm{~nm}$ correspond to ${ }^{5} \mathrm{D}_{0} \rightarrow{ }^{7} \mathrm{~F}_{2}$ transition of $\mathrm{Eu}(\mathrm{III})$ (Cotton, 2006) in ethanol, methanol, and DMF. The sequence of increasing of intensity of the main characteristic emission peak for $\mathrm{Eu}(\mathrm{III})$ at $617 \mathrm{~nm}$ in $\mathrm{Eu}(\mathrm{III})-\mathrm{C}_{1}$ complex is Ethanol $\approx$ DMF > Methanol, for rest of the solvents ethyl acetate, acetonitrile, acetone and water no observed emission peaks of $\mathrm{Eu}(\mathrm{III})$ bands (Figure 3). This behavior interpreted according to solvent effect, in case of DMF and Ethanol both solvents have strong solvation power protecting Eu(III). While in Water, not only the stronger $\mathrm{O}-\mathrm{H}$ oscillator and high coordinating tendency to $\mathrm{Eu}(\mathrm{III})$ but also water effect on excited state of $\mathrm{C}_{1}$ decreasing energy gap between ${ }^{3} \mathrm{~T}^{*}$ and $\mathrm{Eu}(\mathrm{III})$ predicted from red shift in fluorescence spectra of $\mathrm{C}_{1}$ band, this decrease in energy gap may either cancel energy transfer to $\mathrm{Eu}$ (III) or complete quench of $\mathrm{Eu}$ (III) by non-radiative vibrations of water molecule.

$\mathrm{C}_{1}$ shows strong emission peak in $\mathrm{Eu}(\mathrm{III})-\mathrm{C}_{1}$ complex. This band differs in intensity and wavelength from solvent to another. In water coumarin exhibits extremely strong emission peak at $\lambda_{\mathrm{Cl}}=462 \mathrm{~nm}$ at low sensitivity the fluorescence in rest of solvents was taken at medium sensitivity. In case of other solvents, the emission peak for coumarin in the complex is observed at $388,392,393$ and $397 \mathrm{~nm}$ in acetonitrile, DMF, ethanol and acetone respectively. The sequence of increasing of $\mathrm{C}_{1}$ emission peak intensity in $\mathrm{Eu}(\mathrm{III})-\mathrm{C}_{1}$ complex is water $>>$ DMF $>$ Methanol $>$ Ethanol $>$ Acetonitrile $>$ Acetone $>>$ Ethyl acetate. Interpretation according to solvent effect as mentioned before that typically, the fluorophore has a larger dipole moment in the excited state $\left(\mu_{\mathrm{E}}\right)$ than in the ground state $\left(\mu_{\mathrm{G}}\right)$ (Lakowicz, 2007). Following excitation, the solvent dipoles can reorient or relax around $\mu_{\mathrm{E}}$, which lowers the energy of the excited state. As the solvent polarity is increased this effect becomes larger, resulting in emission at lower energies or longer wavelengths which make. In this case polarity order water $>$ Methanol $>$ Ethanol $>$ Acetonitrile $>$ DMF $>$ Acetone, this explain why water appeared in much lower energy and much intense intensity. DMF even It lower polar but it has no $\mathrm{H}-\mathrm{X}$ quenchers like Methanol and Ethanol so $\mathrm{C}_{1}$ intensity stronger in DMF.

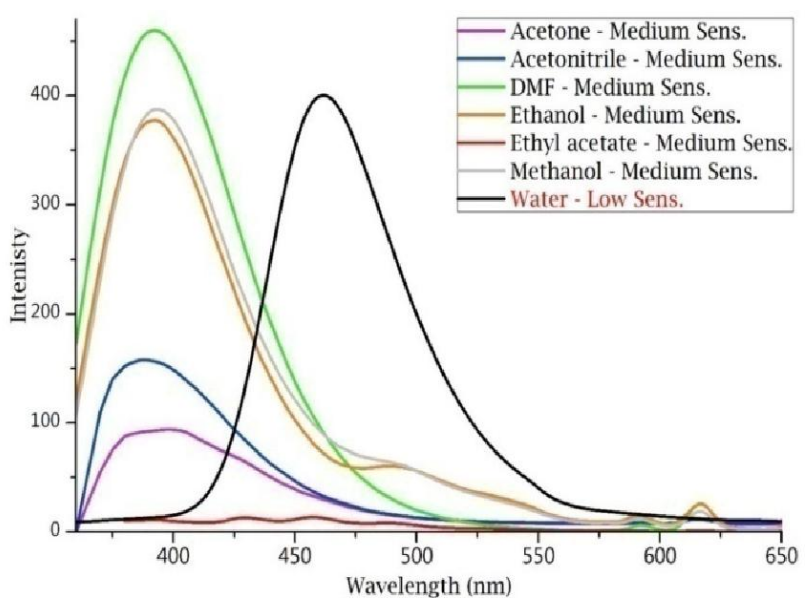

Figure (3): Fluorescence spectrum of $10 \mu \mathrm{mol} / \mathrm{L}$ of $\mathrm{Eu}(\mathrm{III})-\mathrm{C}_{1}[1: 1]$ in different solvents, excitation at $330 \mathrm{~nm}$ at medium sensitivity except in water at low sensitivity and excited at 340nm. 


\section{Interaction of Pesticides with $\mathbf{E u}\left(\right.$ III)-C $\mathbf{C}_{\mathbf{1}}$}

Figure (4) illustrates the fluorescence spectra for

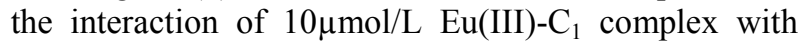
$10 \mu \mathrm{mol} / \mathrm{L}$ of pesticides: Crotoxyphos (P1), Malathion (P2), Dichlorvos (P3), Chlorpyrifos (P4), Paraoxon (P5), Profenofos (P6) and Endosulfan (P7) in ethanol. Two Fluorescence bands are effected differently the $C_{1}$ band at $\lambda_{\mathrm{Cl}}=392 \mathrm{~nm}$ and $\mathrm{Eu}(\mathrm{III})$ characteristic band at $\lambda_{\mathrm{Eu}}=617 \mathrm{~nm}$. Table 1 illustrated the effect on intensity of $\mathrm{Eu}(\mathrm{III})$ band at $\lambda_{\mathrm{Eu}}=617 \mathrm{~nm}$. Quenching by Chlorpyrifos (P4) and enhancement by Crotoxyphos (P1), Dichlorvos (P3), Malathion (P2), Paraoxon (P5) and Endosulfan (P7). Not effect by Profenofos (P6). The effect on $\mathrm{Eu}$ (III) band not tangible enough to consider the interaction unique for specific pesticide. While $C_{1}$ emission peak in $\mathrm{Eu}(\mathrm{III})-\mathrm{C}_{1}$ affected by pesticides in two manner, first is shift in peak and most interested red shift by Crotoxyphos (P1) where $\lambda_{\mathrm{C} 1}$ shifted from $392 \mathrm{~nm}$ to $412 \mathrm{~nm}$ and rest of pesticide has no change in peak position. The second effect on peak intensity where it is quenched by Paraoxon (P5) and Endosulfan (P7), while it is enhanced by Chlorpyrifos (P4), Crotoxyphos (P1), Dichlorvos (P3) and Profenofos (P6), then Malathion (P2) has no effect on intensity.

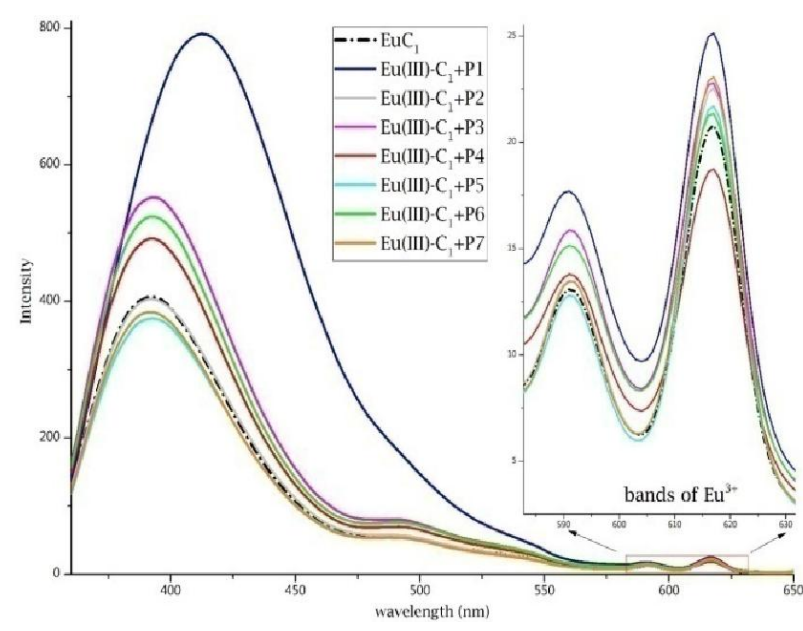

Figure (4): Fluorescence spectra for the interaction of $[10 \mu \mathrm{mol} / \mathrm{L}] \mathrm{Eu}(\mathrm{III})-\mathrm{C}_{1}$ complex with $[10 \mu \mathrm{mol} / \mathrm{L}]$ of different pesticides Crotoxyphos (P1), Malathion (P2), Dichlorvos (P3), Chlorpyrifos (P4), Paraoxon (P5), Profenofos (P6) and Endosulfan (P7) in ethanol, $\lambda_{\mathrm{exc}}=330 \mathrm{~nm}$ at medium Sensitivity.

Table (1): Interaction of $10 \mu \mathrm{mol} / \mathrm{L}$ of pesticide on fluorescence of $10 \mu \mathrm{mol} / \mathrm{L} \mathrm{Eu}(\mathrm{III})-\mathrm{C}_{1}$ in ethanol, the change if intensity and shift of $\mathrm{C}_{1}$ band.

\begin{tabular}{|c|c|c|c|c|c|c|c|}
\hline \multirow{2}{*}{ Sample } & \multicolumn{4}{|c|}{$C_{1}\left[\lambda_{C 1}=392 \mathrm{~nm}\right]$} & \multicolumn{3}{|c|}{$\mathrm{Eu}^{3+}\left[\lambda_{\mathrm{Eu}}=617 \mathrm{~nm}\right]$} \\
\hline & $\Delta \lambda$ & $I_{C_{1}} / I_{C_{1}}^{0} *$ & Effect & $\%$ & $I_{E u} / I_{E u}^{0} * *$ & Effect & $\%$ \\
\hline $\begin{array}{c}\mathbf{E u}(\mathrm{III})- \\
\mathrm{C}_{1}+\mathrm{P} 1\end{array}$ & +20 & 1.95 & Enh. & $95 \%$ & 1.19 & Enh. & $19 \%$ \\
\hline $\begin{array}{c}\mathrm{Eu}(\mathrm{III})- \\
\mathrm{C}_{1}+\mathrm{P} 2\end{array}$ & 0 & 1.00 & Nill & $0 \%$ & 1.10 & Enh. & $10 \%$ \\
\hline $\begin{array}{c}\mathrm{Eu}(\mathrm{III})- \\
\mathrm{C}_{1}+\mathrm{P3}\end{array}$ & +1 & 1.36 & Enh. & $36 \%$ & 1.10 & Enh. & $10 \%$ \\
\hline $\begin{array}{c}\mathrm{Eu}(\mathrm{III})- \\
\mathrm{C}_{1}+\mathrm{P} 4\end{array}$ & 0 & 1.19 & Enh. & $19 \%$ & 0.95 & Q. & $-5 \%$ \\
\hline $\begin{array}{c}\mathrm{Eu}(\mathrm{III})- \\
\mathrm{C}_{1}+\mathrm{P5}\end{array}$ & +1 & 0.92 & Q. & $-8 \%$ & 1.05 & Enh. & $5 \%$ \\
\hline $\begin{array}{c}\mathrm{Eu}(\mathrm{III})- \\
\mathrm{C}_{1}+\mathrm{P6}\end{array}$ & 0 & 1.29 & Enh. & $29 \%$ & 1.00 & Nill & $0 \%$ \\
\hline $\begin{array}{c}\text { Eu(III)- } \\
\mathrm{C}_{1}+\mathrm{P7}\end{array}$ & 0 & 0.95 & Q. & $-5 \%$ & 1.10 & Enh. & $10 \%$ \\
\hline
\end{tabular}

$*$,** $\mathrm{I} / \mathrm{I}_{0}$ if $<1$ mean quenching, $>1$ enhancement

Fluorescence of Eu(III)-C $\mathrm{C}_{1}$ with Crotoxyphos P1 Comparison between Fluorescence Spectra of P1 with $C_{1}$ in Presence and Absence of Eu(III)

The interaction of Crotoxyphos with $\mathrm{Eu}(\mathrm{III})-\mathrm{C}_{1}$ complex observed with respect to $\mathrm{C}_{1}$ emission peak $\lambda_{\mathrm{Cl}}=392 \mathrm{~nm}$ where it is more interesting than $\mathrm{Eu}(\mathrm{III})$ emission band because of the red shift in $\mathrm{C}_{1}$ peak from $392 \mathrm{~nm}$ to $412 \mathrm{~nm}$ with large enhancement $\left(\mathrm{F} / \mathrm{F}_{0}=1.95\right)$. Figure (5) shows the difference between interaction of $\mathrm{P} 1$ on $\mathrm{C}_{1}$ emission peak in absence $\mathrm{Eu}^{3+}$ and on $\mathrm{Eu}(\mathrm{III})$ -
$\mathrm{C}_{1}$ complex. The interaction of $\mathrm{C}_{1}$ with Crotoxyphos (P1) which shows shift of $\lambda_{\mathrm{C} 1}$ from $389 \mathrm{~nm}$ to $403 \mathrm{~nm}$ $\left(\Delta \lambda_{\mathrm{Cl}}=14\right)$ and increase in intensity by $7.5 \%$ while in $\mathrm{Eu}(\mathrm{III})-\mathrm{C}_{1}$ complex the $\Delta \lambda_{\mathrm{Cl}}=22$ and enhancement by $108 \%$, this shows more sensitivity to $\mathrm{P} 1$ in presence of $\mathrm{Eu}(\mathrm{III})-\mathrm{C}_{1}$ complex. In this work rest of studies focus on the effect of $\mathrm{P} 1$ on emission peak of $\mathrm{C}_{1}$ in $\mathrm{Eu}(\mathrm{III})-\mathrm{C}_{1}$ complex based on pervious publish work (El-Shekheby et al., 2014; Féau et al., 2009). 

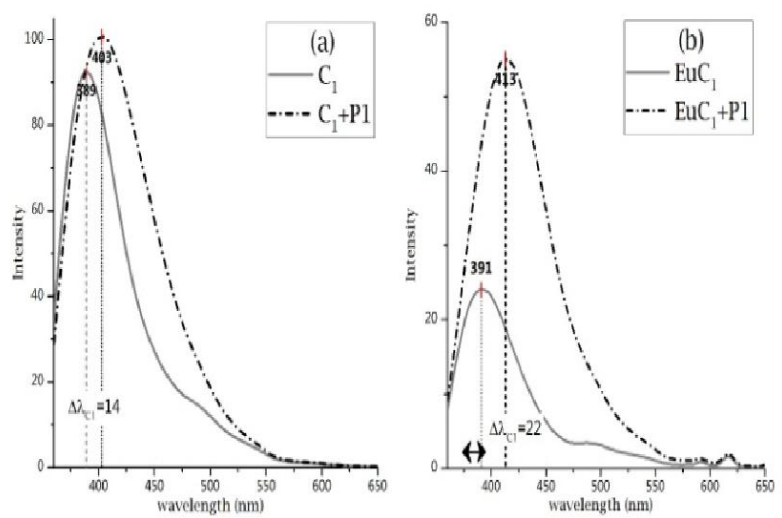

Figure (5):Interaction of $10 \mu \mathrm{mol} / \mathrm{L}$ Crotoxyphos P1 with fluorescence of (a) $10 \mu \mathrm{mol} / \mathrm{L} \mathrm{C}_{1}$ and (b) $10 \mu \mathrm{mol} / \mathrm{L}$

$\mathrm{Eu}(\mathrm{III})-\mathrm{C}_{1}$ in ethanol, $\lambda_{\mathrm{ex}}=330 \mathrm{~nm}$, low sensitivity.

\section{Calibration Curve and LOD-LOQ}

Relation between intensity of $\mathrm{C}_{1}$ band at $\lambda_{\mathrm{Cl}}=392 \mathrm{~nm}$ versus the concentration of $\mathrm{P} 1$ is shown in Figure (6). From calibration plot the correlation coefficient $\mathrm{R}^{2}=0.926$ which an indicative that regression line perfectly fits the data. The limit of detection $(\mathrm{LOD})=1.86 \mu \mathrm{mol} / \mathrm{L}$ and limit of quantitation $(\mathrm{LOQ})=6.19 \mu \mathrm{mol} / \mathrm{L}$ calculated from calibration plot (Shrivastava and Gupta, 2011).

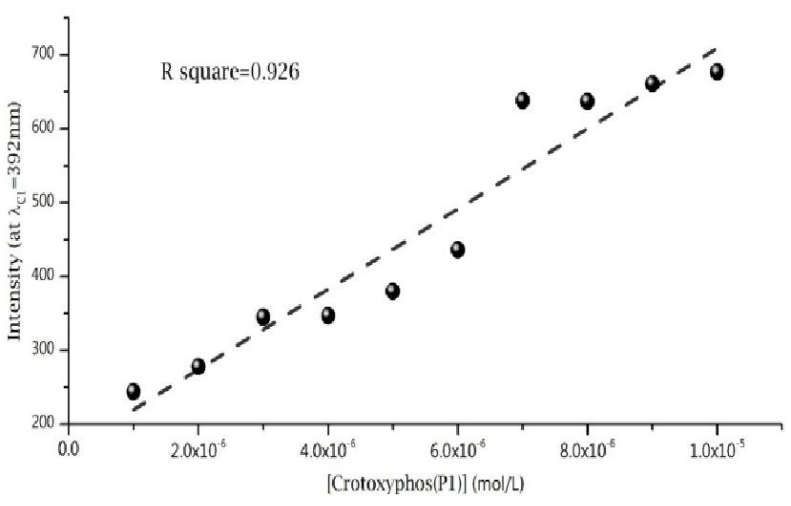

Figure (6): Calibration plot for estimating P1 using $\mathrm{Eu}(\mathrm{III})-\mathrm{C}_{1}$ at $22^{\circ} \mathrm{C}$.

\section{Determining Binding Constant $\left(\mathrm{K}_{\mathrm{b}}\right)$}

The binding constants $\left(K_{\mathrm{b}}\right)$ at different temperatures were calculated based on Benesi-Hildebrand equation (eq. 1) (El-Shekheby et al., 2014; Dalapati et al.,2011).

$$
\frac{1}{F-F_{0}}=\alpha+\frac{\alpha}{K_{b}[Q]} \text {, where } \alpha=\frac{1}{F_{L}-F_{0}}
$$

Where [Q] represents the analytical concentration of $\mathrm{P} 1, F_{0}$ and $F$ are the fluorescence intensities in the absence and presence of Crrotoxyphos pesticide and $\alpha=\frac{1}{F_{L}-F_{0}}$.

Figure (7) illustrates the relation $1 /[\mathrm{P} 1]$ versus $1 / F$ $F_{0}$ at three temperatures; 22,30 and $40^{\circ} \mathrm{C}$. From slope and intercept the binding constant was calculated at each temperature. $K_{\mathrm{d}}=4.2 \times 10^{3}, 15.6 \times 10^{3}, 52 \times 10^{3} \mathrm{~L} \mathrm{~mol}^{-}$ ${ }^{1}$ at 22,30 and $40^{\circ} \mathrm{c}$ respectively (Table 2 ).
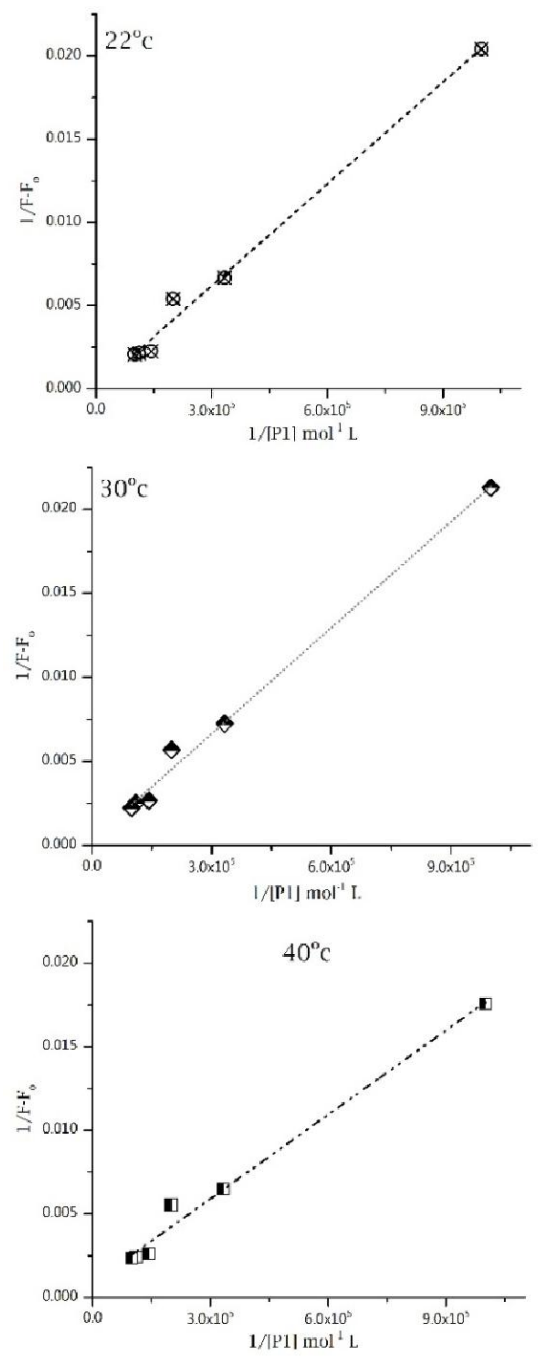

Figure (7): Benesi-Hildebrand and relation plot $1 / F-F_{0}$ versus $1 /[\mathrm{P} 1]$ in ethanol at different temperature 22,30 and $40{ }^{\circ} \mathrm{c}$ with correlation coefficient $\left(\mathrm{R}^{2}\right) 0.991,0.993$ and 0.986 respectively.

\section{Thermodynamic Parameters and the Nature of the Binding Forces}

The binding constant values dependence on temperature was calculated in order to get more information about the forces acting between $\mathrm{P} 1$ and $\mathrm{Eu}(\mathrm{III})-\mathrm{C}_{1}$. The thermodynamic parameters, enthalpy change $(\Delta \mathrm{H})$, entropy change $(\Delta \mathrm{S})$ and Gibbs energy change $(\Delta G)$ are the main quantities utilized to determine the binding mode. The thermodynamic parameters were deduced using Eq. 2-3. The $\Delta \mathrm{H}$ and $\Delta \mathrm{S}$ of the binding reaction were the main thermodynamic parameter to determine binding modes. From The thermodynamic standpoint, where $\Delta \mathrm{H}>0$ and $\Delta \mathrm{S}>0$ reflects a hydrophobic interaction; $\Delta \mathrm{H}<0$ and $\Delta \mathrm{S}<0$ reflects the Vander Waals force or hydrogen bond formation and $\Delta \mathrm{H}<0$ and $\Delta \mathrm{S}>0$ suggesting an electrostatic force (Ross and Subramanian, 1981). The binding constant $\mathrm{K}_{\mathrm{b}}$ was deduced utilizing Benesi- 
Hildebrand equation, then using Van't Hoff equation (eq. 2) (Azab et al.,2013).

$$
\mathrm{LnK}_{\mathrm{b}}=-[\Delta \mathrm{H} / \mathrm{RT}]+[\Delta \mathrm{S} / \mathrm{R}]
$$

Figure (8) shows Van't Hoff plot for P1 with $\mathrm{Eu}(\mathrm{III})-\mathrm{C}_{1}$ with correlation coefficient $\mathrm{R}^{2}=0.995$. The plot is linear relationship with negative slope, the reaction is endothermic interaction between $\mathrm{P} 1$ with $\mathrm{Eu}(\mathrm{III})-\mathrm{C}_{1}$. The thermodynamic parameters are collected in Table 2, where the enthalpy $\Delta H=107 \mathrm{KJ}_{\mathrm{mol}}{ }^{-1}$,

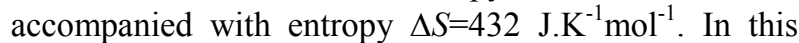
case the interaction could be attributed to hydrophobic type. Gibbs free energy calculated at different temperatures using standard Gibbs free energy equation (eq. 3) (Atkins et al., 2009), the negative values of free energy change $\Delta G^{0}$ associated with the reaction indicated that the interaction of $\mathrm{Eu}(\mathrm{III})-\mathrm{C}_{1}$ complex with pesticide is spontaneous $\left(\Delta \mathrm{G}_{295}=-20.6, \Delta \mathrm{G}_{303}=-24.07\right.$, $\Delta \mathrm{G}_{313}=-28.39 \mathrm{KJ} \mathrm{mol}^{-1}$ ).

$$
\Delta \mathrm{G}=\Delta \mathrm{H}-\mathrm{T} \Delta \mathrm{S} \text { (Error! Bookmark not defined.) }
$$

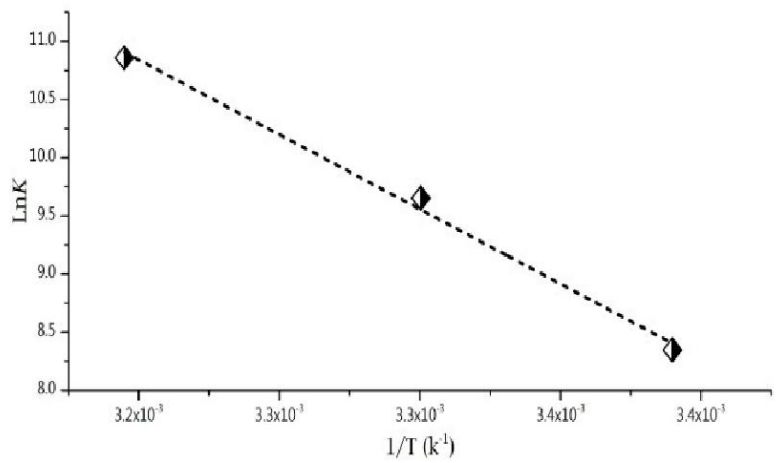

Figure (8): Van't Hoff plot for interaction of Eu(III)- $\mathrm{C}_{1}$ with Crotoxyphos (P1) in Ethanol.

\begin{tabular}{|c|c|c|c|}
\hline \multirow{2}{*}{ Thermodynamic Parameter } & \multicolumn{3}{|c|}{ Temperature } \\
\hline & $295 \mathrm{~K}$ & $303 \mathrm{~K}$ & 313K \\
\hline $\mathbf{K}_{\mathbf{b}}\left(\mathbf{L} \cdot \mathbf{m o l}^{-1}\right)$ & $4.2 \times 10^{3}$ & $15.6 \times 10^{3}$ & $52 \times 10^{3}$ \\
\hline$\Delta \mathbf{H}\left(\mathrm{KJ} . \mathrm{mol}^{-1}\right)$ & & 107 & \\
\hline$\Delta S\left(J \cdot \mathbf{m o l}^{-1} \mathbf{K}^{-1}\right)$ & & 432 & \\
\hline$\Delta \mathbf{G}\left(\mathrm{KJ} \cdot \mathrm{mol}^{-1}\right)$ & -20.6 & -24.1 & -28.4 \\
\hline
\end{tabular}

Table (2): Thermodynamic parameters involve the interaction of $\mathrm{Eu}(\mathrm{III})-\mathrm{C}_{1}$ with Crotoxyphos.

Effect of interfering ions on estimation of Crotoxyphos using Eu(III)-C $\mathrm{C}_{1}$ complex:

Pesticides in environment present with varieties of natural occurring salts and may be other contaminates(Manahan, 2010).In order to develop selective probe for detection of Crotoxyphos using
$\mathrm{Eu}(\mathrm{III})-\mathrm{C}_{1}$ complex the effect of interfering anions and cations present in environment must be studied. Table (4) summarizes the data obtained from studying most important anion, cation and also the interference of other pesticides.

Table (3): Effect of interfering Anions, Cations, and Pesticides on fluorescence spectra of Eu(III)-C $\mathrm{C}_{1}$ complex with

\begin{tabular}{|c|c|c|c|c|c|}
\hline \multicolumn{2}{|c|}{$\begin{array}{c}\text { Interfering Anion } \\
\text { Tolerance 5\% (mg/L) }\end{array}$} & \multicolumn{2}{|c|}{$\begin{array}{c}\text { Interfering Cation } \\
\text { Tolerance } 5 \%(\mathrm{mg} / \mathrm{L})\end{array}$} & \multicolumn{2}{|c|}{$\begin{array}{l}\text { Interfering Pesticides } \\
\text { Tolerance } 5 \%(\mathrm{mg} / \mathrm{L})\end{array}$} \\
\hline $\mathrm{HPO}_{4}{ }^{2-}$ & 0.01 & $\mathrm{Ni}^{2+}$ & 0.09 & \multirow{2}{*}{ Dichlorvos } & \multirow{2}{*}{5.52} \\
\hline $\mathrm{NO}_{3}^{-}$ & 0.1 & $\mathrm{NH}_{4}{ }^{+}$ & 0.27 & & \\
\hline $\mathrm{CO}_{3}{ }^{2-}$ & 0.54 & $\mathbf{N a}^{+}$ & 0.29 & \multirow[b]{2}{*}{ Chlorpyrifos } & \multirow[b]{2}{*}{17.53} \\
\hline $\mathrm{H}_{2} \mathrm{PO}_{4}^{-}$ & 0.01 & $\mathbf{K}^{+}$ & 0.39 & & \\
\hline $\mathrm{Br}^{-}$ & 0.4 & $\begin{array}{l}\mathbf{P b}^{2+} \\
\mathbf{C d}^{2+}\end{array}$ & 1.06 & Paraoxon & 6.88 \\
\hline $\mathbf{I}^{-}$ & 0.69 & $\mathrm{Ca}^{2+}$ & 0.6 & Endosulfan & 4.07 \\
\hline
\end{tabular}
Crotoxyphos. 
7-hydroxy coumarin-4-aceticacid reacts rapidly with Eu(III) in solution and also rapidly interacted with pesticides under study. Promising selectivity toward Crotoxyphos in $\mu \mathrm{M}$-range. Future study focus on introducing allyl group to $\mathrm{C}_{1}$ ligand in order to prepare molecularly imprinted polymers (MIP) for detection of Organophosphorous pesticides specially Crotoxyphos able to be used commercially in environmental analysis.

\section{ACKNOWLEDGEMENT}

Dedicated to the spirit of Prof. Dr. Hassan Ahmed Azab who pass away this year. Completing this work for the sake of proceeding his legacy and leadership in the field of Fluorescence and Analytical chemistry in Chemistry Department in Faculty of Science, Suez Canal University.

\section{REFERENCES}

Anonymous (1996). Organophosphorous Pesticides. Pesticides News No.34, December 1996, p 20 21. http://www.panuk.org/pestnews/Actives/ organoph.htm.

Atkins, P., J. de Paula and R. Friedman (2009). Quanta, Matter, and Change: A Molecular Approach to Physical Chemistry: OUP Oxford.

Azab, H. A., A. Duerkop, Z. M. Anwar, B. H. M. Hussein, M. A. Rizk and T. Amin (2013). Luminescence recognition of different organophosphorus pesticides by the luminescent Eu(III)-pyridine-2,6-dicarboxylic acid probe. Analytica Chimica Acta, 759: 81-91.

Bin Liu, Peng Zhou, Xiaoming Liu, Xin Sun, Hao Li, and Mengshi Lin (2013). Detection of Pesticides in Fruits by Surface-Enhanced Raman Spectroscopy Coupled with Gold Nanostructures. Food Bioprocess Technol, 6: 710-718.

Bucura, B., D. Fournier, A. Danet and Jean-Louis Marty (2006). Biosensors based on highly sensitive acetylcholinesterases for enhanced carbamate insecticides detection. Analytica Chimica Acta, 562: 115-121.

Bünzli, J. G. and S. V. Eliseeva (2011). Basics of Lanthanide Photophysics. In Lanthanide Luminescence: Photophysical, Analytical and Biological Aspects, edited by Pekka Hänninen and Harri Härmä, 1-45. Berlin, Heidelberg: Springer Berlin Heidelberg.

Carlo, M. D., M. Mascini, A. Pepe, G. Diletti and D. Compagnone (2004). Screening of food samples for carbamate and organophosphate pesticides using an electrochemical bioassay. Food Chemistry, 84: 651-656.

Cotton, S. (2006). Lanthanide and Actinide Chemistry. England: John Wiley \& Sons.

Dalapati, S., B. K. Paul, S. Jana and N. Guchhait (2011). Highly selective and sensitive fluorescence reporter for toxic $\mathrm{Hg}$ (II) ion by a synthetic symmetrical azine derivative. Sensors and Actuators B: Chemical, 157 (2): 615-620. doi: http://dx.doi.org/10.1016/j.snb.2011.05.034.
Doick, K. J., N. Dew and K. T. Semple (2005). Linking Catabolism to Cyclodextrin Extractability: Determination of the Microbial Availability of PAHs in Soil. Environmental Science and Technology, 39: 8858-8864.

El-Shekheby, H. A., A. H. Mangood, S. M. Hamza, A. S. Al-Kady and E. M. Ebeid (2014). A highly efficient and selective turn-on fluorescent sensor for $\mathrm{Hg} 2+, \mathrm{Ag}+$ and $\mathrm{Ag}$ nanoparticles based on a coumarin dithioate derivative. Luminescence, 29 (2): 158-167. doi: 10.1002/bio.2521.

Féau, C., E. Klein, P. Kerth and L. Lebeau (2009). Synthesis and properties of europium complexes derived fromcoumarin-derivatized azamacrocycles. Synthetic Metals, 159 (5-6): 528-536.

Hussein, B. H. M., G. M. Khairy and R. M. Kamel (2016). Fluorescence sensing of phosdrin pesticide by the luminescent Eu(III)- and Tb(III)bis (coumarin-3-carboxylic acid) probes. Spectrochimica Acta Part A: Molecular and Biomolecular Spectroscopy, 158: 34-42.

Jenkins, A. L., O. M. Uy and G. M. Murray (1999). Polymer-Based Lanthanide Luminescent Sensor for Detection of the Hydrolysis Product of the Nerve Agent Soman in Water. Analytical Chemistry, 71: 373-378.

Lakowicz J. R. (2007). Principles of Fluorescence Spectroscopy: Springer US.

Liu, G. and Lin Y. (2005). Electrochemistry Communications 7:339-343.

Manahan, S. E. (2010). Water Chemistry: Green Science and Technology of Nature's Most Renewable Resource: Taylor \& Francis.

Mulchandani, P., W. Chen and A. Mulchandani (2006). Microbial biosensor for direct determination of nitrophenyl substituted organophosphate nerve agents using genetically engineered Moraxella sp. Analytica Chimica Acta, 568: 217-221.

Nguyen, T. H. D., Z. Zhang, A. Mustapha, H. Li and M. Lin (2014). Use of Graphene and Gold Nanorods as Substrates for the Detection of Pesticides by Surface Enhanced Raman Spectroscopy. Journal of Agricultural and Food Chemistry 62 (43): 10445-10451.

Obare, S. O., C. De, W. Guo, T. L. Haywood, T. A. Samuels, C. P. Adams, N. O. Masika, D. H. Murray, G. A. Anderson, K. Campbell and K. Fletcher (2010). Fluorescent Chemosensors for Toxic Organophosphorus Pesticides: A Review. Sensors 10 (7): 7018.

Rainina, E. I.., E. N. Efremenco, S. D. Varfolomeyev, A. L. Simonian and J. R. Wildt (1996). The development of a new biosensor based on recombinant E. coil for the direct detection of organophosphorus neurotoxins. Biosensors \& Bioelectronics 11: 991-1000.

Ristori, C., C. Del Carlo, M. Martini, A. Barbaro and A. Ancarani (1996). Potentiometric detection of pesticides in water samples. Analytica Chimica Acta, 325: 151-160.

Ross, P. D. and S. Subramanian (1981). Thermodynamics of protein association 
reactions: forces contributing to stability." Biochemistry 20(11): 3096-3102.

Russell, R. J., M. V. Pishko, A. L. Simonian and J. R. Wild (1999). Poly (ethylene glycol) HydrogelEncapsulated Fluorophore-Enzyme Conjugates for Direct Detection of Organophosphorus Neurotoxins. Analytical Chemistry, 71: 49094912.

Sawhney, B. L., K.. W. Brown (1989). Reactions and movement of organic chemicals in soils: Soil Science Society of America. Soil Science Society of America and American Society of Agronomy. Madison, WI. 431pp.

Shrivastava, A. and V. B Gupta (2011). Methods for the determination of limit of detection and limit of quantitation of the analytical methods. Chronicles Young Scientists 2 (1): 21-25.

Simonian, A. L., J. K. Grimsley, A. W. Flounders, J. S. Schoeniger, Tu-Chen Cheng, J. J. DeFrank and J. R. Wild (2001). Enzyme-based biosensor for the direct detection of fluorine-containing organophosphates. Analytica Chimica Acta 442: $15-23$.

Singh, B. K. and A. Walker (2006). Microbial degradation of organophosphorus compounds. FEMS microbiology reviews, 30(3): 428-471.

Tang, T., J. Deng, M. Zhang, G. Shi and T. Zhou (2016). Quantum dot-DNA aptamer conjugates coupled with capillary electrophoresis: A universal strategy for ratiometric detection of organophosphorus pesticides. Talanta, 146: 5561.

Vakurov, A., C. E. Simpson, C. L. Daly, T. D. Gibson, and P. A. Millner (2004). Acetylcholinesterasebased biosensor electrodes for organophosphate pesticide detection - Modification of carbon surface for immobilization of acetylcholinesterase. Biosensors and Bioelectronics, 20: 1118-1125.

Viveros, L., S. Paliwal, D. McCrae and A. S. J. Wildb (2006). A fluorescence-based biosensor for the detection of organophosphate pesticides and chemical warfare agents. Sensors and Actuators B, 115: 150-157.

Yi He, Bo Xu, Wenhao Li, and Haili Yu (2015). Silver Nanoparticle-Based Chemiluminescent Sensor Array for Pesticide Discrimination." Journal of Agricultural and Food Chemistry, 63: 2930-2934.

Yihe Hu, W. Pinkham, L. A. French Jr., D. Frankel and J. F. Vetelino (2005). Pesticide detection using a lateral field excited acoustic wave sensor. Sensors and Actuators B, 108: 910-916.

Zhang, K., Q. Mei, G. Guan, B. Liu, S. Wang and Z. Zhang (2010). Ligand Replacement-Induced Fluorescence Switch of Quantum Dots for Ultrasensitive Detection of Organophosphorothioate Pesticides. Analytical Chemistry, 82: 9579-9586.

\section{الكثف الومضي لمبيد الكروتوكسيفوس بإستخدام متراكب الأوروبيوم مع مشتق الكومارين

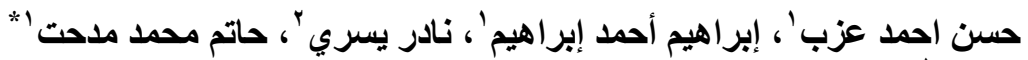

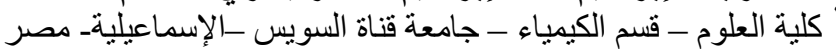

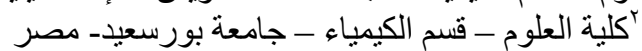

متر اكب الاوروبيوم الو امض مع مركب V - هيبروكسيـ كومارين ـ ـ - حامض الاسيتيكتم، نم دراستة ككانثف عن المبيديدات الفوسفاتية.

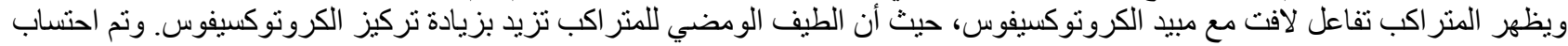

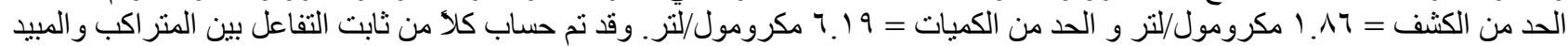

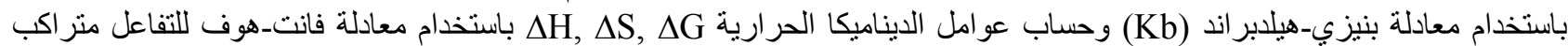

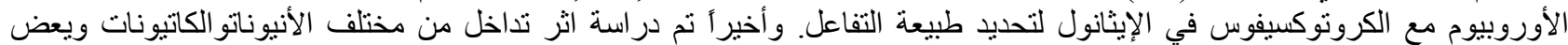
المبيدات و التي قد تتو اجد في البيئة على تقدير الكروتوكسيفوس بإنستخدام متر اكب الأوروبيوم في الإيثانول. 